\title{
STABLE AND UNSTABLE NASAL STEMS IN KHALKHA MONGOLIAN*
}

\author{
ATTILA RÁKOS \\ Eötvös Loránd University, Department of Mongol and Inner Asian Studies, \\ Research Centre for Mongol Studies \\ 1088 Budapest, Múzeum krt. 4/B, Hungary \\ e-mail: rakos@innerasia.hu
}

\begin{abstract}
Declension of nasal stem nouns differs from that of standard consonant and vowel stems. The four nasal stem types discussed in the paper are not strict categories, a wide range of nouns show variance in the use of suffixes characteristic of one or another stem type, and also several examples of semantic split can be observed. Data obtained from the internet using a search engine show the distribution of the alternating forms, the tendencies of certain changes of stem types and also prove the spreading of unstable $n$-stems and velar nasal stems. The most complex phenomenon among Khalkha nasal stem types is the unstable $n$ which is not simply a lexically encoded empty morpheme or a phonological feature in the declension paradigm of a particular noun class, but it has certain grammatical functions as well.
\end{abstract}

Key words: nasal stem types, unstable nasal, stem type alternation, Khalkha Mongolian.

Khalkha noun stems are usually categorised by their stem-final sound and the present paper deals with some (but far not all) synchronic aspects of certain nasal stems. Although noun stems in Khalkha may end in any of the five nasal phonemes present in this dialect $\left(/ \mathrm{n} /, / \mathrm{m} /, / \mathrm{n}^{\mathrm{j}} /, / \mathrm{m}^{\mathrm{j} /}\right.$ or $\left./ \mathrm{y} /\right)$, only stems ending in $/ \mathrm{n} /$ and $/ \mathrm{y} /$ will be discussed here, since these differ from the standard consonant stems in some respects, while other nasal stems do not. Almost all comprehensive works dealing with Khalkha or Mongolian grammar and phonology discuss nasal stems to various extent (e.g. Todaeva 1951, Sanžeev 1953; Poppe 1955; Bosson 1964, Kullmann-Tserenpil 1996, Svantesson 2003), but only some of them go into more detailed description focusing on the synchronic situation, like e.g. Janhunen (2012). There are also studies devoted specially to the problems of nasal stems, including Finch (1987), Jam"yan (1996) and Thompson (2008).

* The present study is part of a research project supported by the Hungarian Scientific Research Fund (OTKA 100613). 
Beside the description of certain aspects and characteristic features of nasal stems, some data will be presented on the distribution of their alternating forms that could be observed in Khalkha Mongolian. There is no public and searchable corpus of Khalkha material containing a significant amount of texts that could be used for precise and thorough linguistic analysis ${ }^{1}$, so only the available resources could be utilised. The largest searchable corpus of Mongolian texts is available in the database of Google's search engine and data presented here are based on Google searches. ${ }^{2}$

Nasal stems ending in $/ \mathrm{n} /$ and $/ \mathrm{n} /$ in their isolation form (nominative) differ not only from the standard consonant stems, but also from each other. These two stem-final phonemes correspond to three distinct stem classes and imply the existence of three underlying morphophonemes: $/ / \mathrm{n}_{1} / /, / / \mathrm{n}_{2} / /$ and $/ / \mathrm{y} / /{ }^{3}$. There are also noun stems, that have no nasal ending in their isolation form and usually behave as a standard consonant or vowel stem, but a stem-final nasal $\left(/ / \mathrm{n}_{1} / /\right)$ appears in certain cases (usually referred as unstable, hidden or fleeting $n$ ). Although the classification of these stem types should be based on their synchronic behaviours, the names of the established categories can rely on both historical and synchronic aspects. Thus the four nasal stem types are the following ones:

- primary dental nasal stems or primary $\boldsymbol{n}$-stems $\left(/ / \mathrm{n}_{1} / /\right)$

- secondary dental nasal stems or secondary $\boldsymbol{n}$-stems $\left(/ / \mathrm{n}_{2} / /\right)$

- velar nasal stems or $\boldsymbol{y}$-stems $(/ / \mathrm{y} / /)$

- unstable dental nasal stems or unstable $n$-stems $\left(/ / \mathrm{n}_{1} / /\right)$

Morphophoneme $/ / \mathrm{n}_{1} / /$ of primary and unstable $n$-stems mostly goes back to original stem-final /n/, which was either stable or unstable. In comparison with other Mongolian languages and dialects (especially Oirat and Buriat) a large number of originally stable $n$-stems became unstable in Khalkha. Unstable $n$ also appears frequently in historically non-nasal stems, including inherited native words and recent loanwords, too.

Original velar nasal stems ending in $/ \mathrm{y} /$ retained their final consonant and form the class of $\eta$-stems in today's Khalkha with an underlying morphophoneme $/ / \mathrm{y} / /$. Morphophoneme $/ / \mathrm{n}_{1} / /$ and $/ / \mathrm{y} / /$ have the same surface representation in most cases,

${ }^{1}$ Experimental databases are available, such as the Mongolian corpus at web-corpora.net, but due to their limited content these are not suitable for real research yet. Anyway, building a representative corpus of Mongolian texts for linguistic studies is a target of already ongoing projects in Mongolia.

${ }^{2}$ Searches, the results of which are provided here, were made between 1 and 28 of February 2015 for words and phrases written in the standard Cyrillic orthography (no texts in Latin transcription were taken into account) and were restricted to the .mn top level domain. Phrases containing multiple words were enclosed into quotes in the search expressions. Due to several factors (limited set of search options, restrictions on mass or automated batch searches, uneven content of the corpus, non-transparent searching and indexing algorithms, spelling errors, homophonous words, etc.), the results are certainly not accurate, not representative, do not cover all possible forms and may change by time, but they definitely show the real tendencies.

${ }^{3}$ Janhunen (2012, pp. 64-66) uses $n, n$ ' and $n g$ to indicate the same morphophonemes. 
and their original distinction has been neutralised in these positions - the distinction is present only before long (full) vowels (see the table below).

Final $/ / n_{2} / /$ of secondary $n$-stems goes back to original $/ n V /$ clusters, where the final vowel has been elided and the nasal consonant became the stem-final sound. This $/ / \mathrm{n}_{2} / /$ has a single $[\mathrm{n}]$ surface representation in all positions, though due to the interference with surface forms of $/ / \mathrm{n}_{1} / /$ and $/ / \mathrm{y} / /$, the distinction between $/ / \mathrm{n}_{2} / /$ and the other two nasal morphophonemes is also neutralised before vowels and coronal consonants. ${ }^{4}$

\section{Surface representations of the stem-final consonants in the nasal stems ${ }^{5}$}

\begin{tabular}{|c|c|c|c|c|c|c|c|}
\hline & & Cyrillic & I_\# & I_V & /_[+labial] & /_[+coronal] & /_[+velar] \\
\hline$y$-stem & $/ / \mathrm{y} / /$ & $<_{\mathrm{H}}>$ & \multirow{3}{*}[\mathrm{y}]{} & [ng] & \multirow{3}{*}[\mathrm{m}]{} & \multirow{4}{*}[\mathrm{n}]{} & {$[\mathrm{n}]$} \\
\hline primary $n$-stem & \multirow{2}{*}{$/ / \mathrm{n}_{1} / /$} & $<_{\mathrm{H}}>$ & & \multirow{3}{*}[\mathrm{n}]{} & & & \multirow{3}{*}{-} \\
\hline unstable $n$-stem & & $<_{\mathrm{H}}>$ & & & & & \\
\hline secondary n-stem & $/ / \mathrm{n}_{2} / /$ & $<_{\mathrm{HV}}>$ & [n] & & {$[\mathrm{n}]$} & & \\
\hline
\end{tabular}

Further sample texts will be rendered in Cyrillic letters using the official Khalkha orthography. The stem class of nasal noun stems will be indicated where necessary: an additional slash and letter $\mu$ indicate unstable $n$-stems (e.g. иирээ/ $\mu$ 'table', морь/н 'horse') ${ }^{6}$, while a slash and 2 indicate velar nasal stems (e.g. байшин/ح 'building', булчин/2 'muscle'). Secondary $n$-stems are recognisable by their final на/нэ/но/нө (e.g. шинэ 'new', багана 'column') and primary $n$-stems by final $н$ (e.g. улаан 'red', $x_{Y H}$ 'man'). If the stem class is rather ambiguous, a question mark will be placed to indicate it.

\section{Basic Characteristics of Nasal Stem Types}

All four nasal stem types have some characteristic features distinguishing them from standard consonant stems and also from each other. Declension of primary $n$-stem nouns differs from that of standard consonant stems in the suffix of the genitive case: it is $-u \check{u} / b l$ instead of the standard -ийн/ьин (e.g. хаан 'khan' + GEN $\rightarrow$ xaаныl). Another difference is the relatively frequent occurrence of plural marker $-\partial$ which replaces the

${ }^{4}$ For further details of the phonetic features of nasal stems see Janhunen (2012, pp. 64-66).

${ }^{5}$ See also Janhunen (2012, pp. 64-66); Svantesson et al. (2005, p. 57).

${ }^{6}$ Although addition of the final nasal may cause changes in the spelling of the stem variant (e.g. морь $\rightarrow$ морин) and also resyllabification may take place (арав $\rightarrow$ арван), these will not be indicated here (as it is done in some dictionaries). 
stem-final sound and is typical of primary and unstable $n$-stems (e.g. эрдэмтэн 'scholar' + PLUR $\rightarrow$ эрдэмтэә). ${ }^{7}$

Unstable $n$-stem nouns behave exactly the same way as primary $n$-stems when their final nasal appears. Unstable $n$ appears before certain case markers (GEN, DAT, $\mathrm{ABL}$ ), plural suffix $-У У \partial ~(1)$ and some postpositions, as well as in attributive position. When the stem-final nasal is hidden, such nouns are indistinguishable from standard consonant or vowel stems.

a иирээ/н 'table' $\rightarrow$ GEN: иирээний, DAT: иирээнд, ABL: ширээнээс, PLUR: ширээн $ү Y \partial$

b хувиас/н 'clothe' $\rightarrow$ GEN: хувцасны, DAT: хувцุасанд, ABL: хувиаснаас, PLUR: хувиаснууд

c морь/н 'horse' $\rightarrow$ GEN: морины, DAT: моринд, ABL: мориноос; PLUR: моринууд (the standard is морид)

There is no restriction on the final sound of the unstable $n$-stems' short variant, except $/ \mathrm{y} /$ (including surface form of both $/ / \mathrm{y} / /$ and $/ / \mathrm{n}_{1} / /$ ), which does not occur due to phonotactic reasons: an epenthetic vowel/a/ appears before unstable $n$ if the final sound of the short stem variant is a consonant, so this consonant shifts to syllable onset, but $/ \mathrm{y} /$ is not possible in this position. A final diphthong is not impossible, but rare, and such nouns often have a defective unstable $n$-stem paradigm and classified in dictionaries as standard vowel stems (e.g. нохой 'dog'). The latter phenomenon seems to be quite old in Khalkha and was present already in the 19th century as Gábor Bálint of Szentkatolna described it in his comparative grammar of West and East Mongolian languages written probably in 1882 on the basis of materials collected between 1871 and 1873 in Kalmykia and Mongolia (Birtalan 2009, p. 58 / p. 42).

There are particular derivational suffixes that sometimes or always form unstable $n$-stem nouns. These suffixes are either productive (2) or non-productive (3) in modern Khalkha. Interestingly, unlike $-\iota$ and $-2 \varphi$ suffix $-A A \varphi$ (containing the same $-\varphi$ element) does not form unstable $n$-stems (e.g. судлаач 'researcher', зураач 'painter').
a -(л)гAA $\leftarrow \mathrm{WM} \mathrm{-(la) \gamma a/(le)ge:} \mathrm{ажиллагаa/н} \mathrm{'work,} \mathrm{activity',} \mathrm{баталгаa/н}$ 'confirmation'

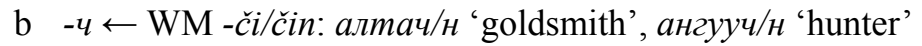

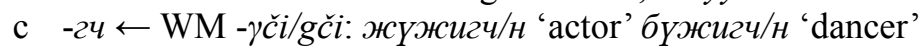
$\mathrm{d}-в ч \leftarrow \mathrm{WM}-b c ̌ i:$ салхивч/H 'vent hole'

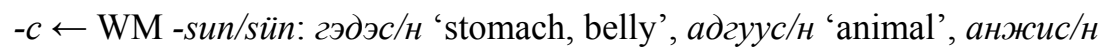

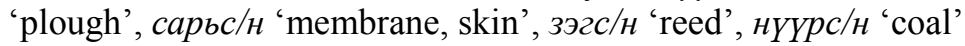

The number of unstable $n$-stem nouns is apparently increasing in Khalkha. Not only native Mongolian nouns turn into unstable $n$-stem type, but a significant percent-

\footnotetext{
${ }^{7}$ The occurrence of $-\partial$ is not predictable. Some multisyllabic consonant stems ending in $/ \mathrm{r} /$ or $/ 1 /$ can also take this plural marker, as well as nouns derived using suffixes $-\iota,-2 \varphi$ and $-A A \varphi$ (all containing the same $-\varphi$ element).
} 
age of recent loanwords also belong to this stem class (e.g. банк/н 'bank', ботинк/н 'shoes', метро/н 'underground').

Secondary $n$-stems mostly behave similarly to standard consonant stems, but the standard genitive case marker $-и \check{u} н / b \iota н$ may alternate with suffix $-u \check{u} / b l$ typical of primary and unstable $n$-stems (see later). The overwhelming part of secondary $n$-stem nouns cover three semantic fields only: (1) plants, mostly derived with suffix $-2 A н A$ (WM -rana/gene), e.g. гүзээлзгэнэ 'strawberry', чацаргана 'sea-buckthorn' (this is by far the largest group), (2) animals, e.g. батгана 'small fly', хулгана 'rat', оготно 'mouse', (3) spatials containing the remnant of an archaic locative (WM -a/e) and a paragogic n, e.g. гадна 'outside', дотно 'inner', өмнө 'before, south', дорно 'east'. The remaining nouns are more diverse, and no strict categories could be established for further division, e.g. иинэ 'new', багана 'column', жинхэнэ 'real', гөлтгөнө 'alabaster'.

Two characteristic features of velar nasal stems are the suffix of the accusative case ( -2 instead of $-u \check{u} z / b l z$ of the standard consonant stems $\left.{ }^{8}\right)$ and the insertion of a connective $/ \mathrm{g} /$ before suffixes beginning with a long vowel: GEN $-u \check{u} н / b \imath н, \mathrm{ABL}-A A c$, INSTR $-A A p$, REF.POSS $-A A$ and PLUR $-У У \partial$ (4). The connective $/ \mathrm{g} / \mathrm{can}$ be analysed as an extension of the stem and also as the initial part of the suffixes (Janhunen 2012, p. 83). Velar nasal stems do not have specific semantic fields, and a significant number of loanwords (mostly of Chinese and Tibetan origin) can be observed among them (e.g. бин/2 'pancake' $\leftarrow$ Chinese bing 'cake', даалин/2 'linen or silk purse' $\leftarrow$ Chinese dā lián 'rectangular bag', гэлэн/ح '(Buddhist) monk' $\leftarrow$ Tibetan dge-slong 'id.').

a байшин/2 'building' $\rightarrow$ ACC: байшинг, GEN: байшингийн, ABL: байшингаас, INSTR: байшингаар, REF.POSS: байшингаа, PLUR: байиингууд

b зуслан/2 'summer camp' $\rightarrow$ ACC: зусланг, GEN: зуслангийн, ABL: зуслангаас, INSTR: зуслангаар, REF.POSS: зуслангаа, PLUR: зуслангууд

c GEN: Үзэсгэлэнгийн, ABL: Үзэсгэлэнгээс, INSTR: Үзэсгэлэнгээр, REF.POSS: Үзэсгэлэнгээ, PLUR: ҮзэсгэлэнгҮY

What concerns denominal derivation, stem-final nasal of primary $n$-stems usually drops out in derived words (5), but there are derivational suffixes $(-\iota,-ч u н)$ where it mostly remains $(6)$, or others $(-m / \partial)$ where it alternates with zero $(7)$.

a цагаан 'white' $\rightarrow$ यагаapax 'to whiten'
b ногоон 'green' $\rightarrow$ ногоовтор 'greenish'
c баян 'rich' $\rightarrow$ баяжих 'to enrich'

${ }^{8}$ Sporadically the standard accusative marker -uŭz also occurs with velar nasal stems (with the connective $/ \mathrm{g} /$ ), but it is very rare and the result lists of such searches in Google contain a lot of misspelled words. 
(6) a

b буян 'merit, blessing' $\rightarrow$ буянч 'virtuous or charitable person'

c хаан 'khan, emperor' $\rightarrow$ *хаанч $\rightarrow$ хаанчлах 'to reign'

d Үймээн 'turmoil' $\rightarrow$ үймээнчин 'trouble-maker'

a улаан 'red' $\rightarrow$ улаандах / улаадах 'to be (too) red'

b бараан 'dark' $\rightarrow$ бараантах 'to be dark'

The nasal of unstable $n$-stems never appears before derivational suffixes (8), and the apparent exceptions are either based on a stable $n$-stem variant of the word or result from older derivations and intentional archaisation (9). Such alternating words as архинч/архич 'drunkard' ( $\leftarrow$ архи/н 'alcoholic drink') саальчин/саалинчин 'milker' (сааль/ 'milking') present in Kara (1998) were found on the internet only without $n$ as архичин and саальчин.

$$
\begin{aligned}
& \text { a морь/н 'horse' } \rightarrow \text { морилох 'to come' } \\
& \text { b авиа/н 'sound' } \rightarrow \text { авиалбар 'phoneme' } \\
& \text { амь/н 'life' } \rightarrow \text { аминч 'selfish' }
\end{aligned}
$$

The stem-final consonant of secondary $n$-stems (10) and velar nasal $\eta$-stems (11) never drops out and it is always retained in derived words. Stem-final $/ / \mathrm{y} / /$ changes to $/ \mathrm{g} /$ before $/ \mathrm{n} /(\leftarrow / 1 /)$ in Khalkha, which is observable in derived words, too (12).

(10) a цинэ 'new' $\rightarrow$ цинэлэх 'to celebrate the new year'

b богино 'short' $\rightarrow$ богинодох 'to be too short'

(11) a бүлэн/2 'blood clot' $\rightarrow$ бүлэнтээ 'to clot'

b жин/2 'load, caravan' $\rightarrow$ жинчин 'caravan-leader, carter'

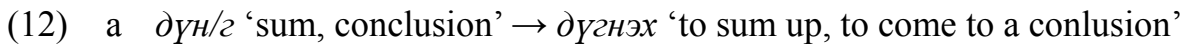

b золбин/2 'vagrant, stray' $\rightarrow$ золбигнох 'to stray, to be homeless'

\section{Alternation of Stem Classes}

Classification of noun stems into the subcategories of nasal stem types is not always consistent and unambiguous, alternations can be observed in numerous cases. One and the same noun stem can fully or partially behave according to the paradigm of more than one stem class. Alternations occur unevenly, sometimes only a certain part of the nominal paradigm shows alternating forms. The ratio of the alternating variants is a unique and characteristic feature of each noun stem concerned, but some conditioning factors (e.g. specificity, concreteness) are also observable. Further studies are required concerning idiolectical, areal, social or other aspects of the distribution of the alternating forms. There are three basic types of stem class alternations in Khalkha, but sporadically other combinations also exist: 
1. secondary $n$-stem $\rightarrow$ primary $n$-stem

2. primary $n$-stem $\rightarrow \eta$-stem

3. standard consonant or vowel stem $\rightarrow$ unstable $n$-stem

The most striking difference between secondary and primary $n$-stem nouns is the suffix of the genitive case marker, which is $-и \breve{u} н / b l н$ at secondary $n$-stems (same as standard consonant stems) and $-u \check{u} / b l$ at primary $n$-stems. This difference, however, seems to be frequently neutralised in favour of the primary $n$-stem type suffix (13). According to the results of Google searches, the extent of alternation is highly dependent on the given lexical item and no clear tendencies could be observed. Beside the genitive suffix, no other features of primary $n$-stems are transferred to secondary $n$-stem nouns.

\begin{tabular}{|c|c|c|}
\hline a эрдэнэ 'gem, jewel' + GEN & $\begin{array}{l}\text { эрдэнийн } 70 \%{ }^{9} \\
(366,000)\end{array}$ & $\begin{array}{l}\text { эрдэний 30\% } \\
(154,000)\end{array}$ \\
\hline b сонгино 'onion' + GEN & $\begin{array}{l}\text { сонгинын } 15 \% \\
(5360)\end{array}$ & $\begin{array}{l}\text { сонгины } 85 \% \\
(295,00)\end{array}$ \\
\hline иинэ 'new' + GEN & $\begin{array}{l}\text { шинийн 94\% } \\
(415,000)\end{array}$ & $\begin{array}{l}\text { шиний } 6 \% \\
(25,000)\end{array}$ \\
\hline d чаиаргана 'sea-buckthorn' + GEN & $\begin{array}{l}\text { чацарганын } 2 \% \\
(6590)\end{array}$ & $\begin{array}{l}\text { чаиарганы } 98 \% \\
(300,000)\end{array}$ \\
\hline e багана 'column' + GEN & $\begin{array}{l}\text { баганын } 35 \% \\
(11,900)\end{array}$ & $\begin{array}{l}\text { баганы 65\% } \\
(21,700)\end{array}$ \\
\hline
\end{tabular}

The distinction of final nasals of primary $n$-stems and velar nasal stems has been neutralised in most positions, thus the isolation form of both stem types ends in [y]. This change motivated a shift of certain primary $n$-stems towards the $\eta$-stem paradigm. A complete change is rare, but the parallel existence and alternation of the two paradigms can be observed frequently. The ratio of the variations is different for each noun: some nouns are quite conservative, while others are not (14). The motivation of the difference is not clear, even nouns with similar structure behave quite differently (e.g. the $\eta$-stem type accusative is $88.6 \%$ for оюу-тан and only $32.6 \%$ for эрдэм-тэн). The use of $\eta$-stem paradigm is most frequent in the accusative case (its proportion reaches up to $98 \%$ at some nouns) and with plural suffix $-У У \partial$ (up to $95 \%$ ), and less frequent in ablative and instrumental. The full change of originally primary $n$-stem nouns to $\eta$-stem type has taken place in few cases, such as хулан/2 'wild ass' ( $\leftarrow$ WM qulan) or Цолмон/2 'morning star' $(\leftarrow$ WM Čolmon $)$.

\footnotetext{
${ }^{9}$ Here and in further exmaples the numbers in parentheses show the number of matches given by Google Search for the given expression, and percentages are calculated from the total sum of matches for all variants.
} 


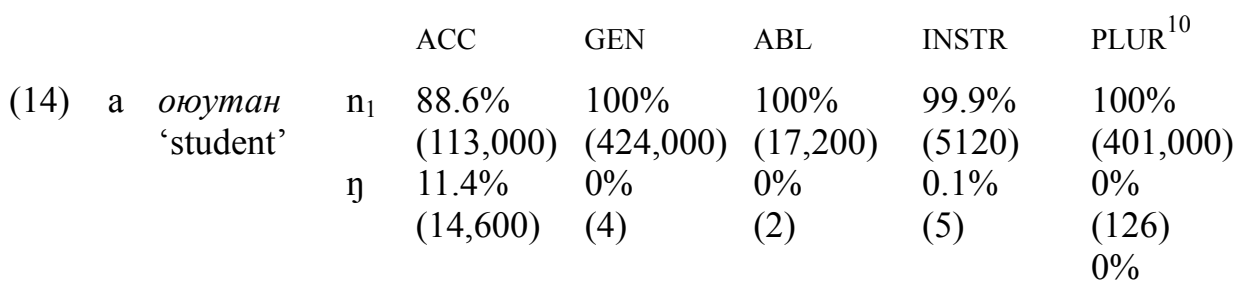

$$
\begin{aligned}
& \text { (24) }
\end{aligned}
$$

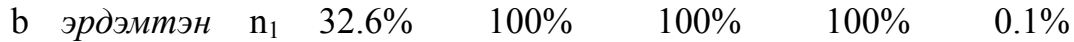

$$
\begin{aligned}
& \begin{array}{llllll} 
& \text { 'scholar' (6930) } \quad(47,300) & (1260) & (10,100) & (477)
\end{array} \\
& \text { y } 67.4 \% \quad 0 \% \quad 0 \% \quad 0 \% \quad 0 \% \\
& \begin{array}{lllll}
(14,300) & (0) & (0) & (0)
\end{array} \\
& 99.9 \% \\
& (411,000) \\
& \begin{array}{lllllll}
\text { c } \begin{array}{c}
\text { начин } \\
\text { 'falcon' }
\end{array} & \mathrm{n}_{1} & \begin{array}{l}
46.6 \% \\
\end{array} & 67.3 \% & 49.3 \% & 54.1 \% & 4.4 \% \\
& \mathrm{n} & 53.4 \% & 32.6 \% & 50.7 \% & 45.9 \% & 95.5 \% \\
& & (4280) & (8260) & (406) & (1690) & (6740) \\
& & & & & & 0 \%
\end{array} \\
& \text { (2) } \\
& \begin{array}{lllllll}
\mathrm{d} \text { малчин } & \mathrm{n}_{1} \quad 30.5 \% & 100 \% & 99.9 \% & 99.9 \% & 0 \%
\end{array} \\
& \text { 'herdsman' (11,496) (211,260) } \quad(3728) \quad(17,700) \quad(3) \\
& \text { y } 69.5 \% \quad 0 \% \quad 0,1 \% \quad 0.1 \% \quad 0 \% \\
& \begin{array}{llll}
(26,200) & \text { (9) (4) } \quad \text { (2) } \quad \text { (9) }
\end{array} \\
& 100 \% \\
& (345,000) \\
& \begin{array}{lllllll}
\text { e ордон } & \mathrm{n}_{1} & 53.9 \% & 99.1 \% & 99 \% & 99.9 \% & 87.2 \% \\
\text { 'palace' } & & (70,530) & (495,000) & (61,670) & (158,020) & (1409) \\
& \mathrm{y} & 66.1 \% & 0.9 \% & 1 \% & 0.1 \% & 12.8 \% \\
& & (60,300) & (4420) & (644) & (213) & (206)^{11}
\end{array}
\end{aligned}
$$

Alternation of standard consonant or vowel stems and unstable $n$-stems is probably the most frequent one. Although most of the unstable $n$-stem nouns go back to diachronically stable or unstable $n$-stems, the domain of unstable $n$-stems is increasing to the detriment of originally standard consonant and vowel stems. The extent of alternation is apparently unique and characteristic of each noun (15). For example, results for байp/ $\mu$ 'residence' show the dominance of $n$-stem variant in genitive $(71.4 \%)$ and ablative cases $(95.5 \%)$, while dative and plural forms are rather bal-

${ }^{10}$ The first two values in this column contain the results for suffix $-У У \partial$, while the third value is the number of occurrences of plural suffix $-\partial$, characteristic of primary $n$-stems.

${ }^{11}$ Because of the homophonous ордод $(\leftarrow$ ордон 'palace' + PLUR - $\partial)$ and ордод $(\leftarrow$ орд '(mine)field' + DAT) the search result $(146,000)$ is ignored here. 
anced (15b). ${ }^{12}$ The genitive form of $y y \pi / H^{\text {? }}$ 'mountain' almost always occurs without $n(98.5 \%)$, but the situation is the opposite in dative $(95.2 \%$ with $n)$ and balanced in ablative and plural (15e).

\begin{tabular}{|c|c|c|c|c|c|c|}
\hline & & & GEN & DAT & ABL & PLUR /-U:d/ \\
\hline (15) & $\begin{array}{l}x \ni л / H \\
\text { 'tongue, language' }\end{array}$ & $\mathrm{n}_{1}$ & $\begin{array}{l}99.1 \% \\
(524,000) \\
0.9 \% \\
(4640)\end{array}$ & $\begin{array}{l}63.4 \% \\
(45,500) \\
36.6 \% \\
(26,300)\end{array}$ & $\begin{array}{l}96 \% \\
(57,700) \\
4 \% \\
(2,430)\end{array}$ & $\begin{array}{l}62.5 \% \\
(5280) \\
37.5 \% \\
(3170)\end{array}$ \\
\hline b & $\begin{array}{l}\text { байр/н } \\
\text { 'residence' }\end{array}$ & $\begin{array}{l}\mathrm{n}_{1} \\
\varnothing\end{array}$ & $\begin{array}{l}71.4 \% \\
(466,000) \\
28.6 \% \\
(187,000)\end{array}$ & $\begin{array}{l}54.9 \% \\
(406,000) \\
* 45.1 \% \\
(334,000)\end{array}$ & $\begin{array}{l}95.5 \% \\
(88,500) \\
4.5 \% \\
(4210)\end{array}$ & $\begin{array}{l}51 \% \\
(309,000) \\
49 \% \\
(297,000)\end{array}$ \\
\hline $\mathrm{c}$ & $\begin{array}{l}\text { хана/н } \\
\text { 'wall' }\end{array}$ & $\begin{array}{l}\mathrm{n}_{1} \\
\varnothing\end{array}$ & $\begin{array}{l}13.9 \% \\
(53,900) \\
86.1 \% \\
(333,000)\end{array}$ & $\begin{array}{l}97.3 \% \\
(81,700) \\
2.7 \% \\
(2230)\end{array}$ & $\begin{array}{l}54.3 \% \\
(6540) \\
45.7 \% \\
(5430)\end{array}$ & $\begin{array}{l}75.3 \% \\
(1490) \\
24.7 \% \\
(490)\end{array}$ \\
\hline d & $\begin{array}{l}\text { цирээ/H } \\
\text { 'table' }\end{array}$ & $\begin{array}{l}\mathrm{n}_{1} \\
\varnothing\end{array}$ & $\begin{array}{l}99.6 \% \\
(346,000) \\
0.4 \% \\
(1350)\end{array}$ & $\begin{array}{l}99.8 \% \\
(67,900) \\
0.2 \% \\
(117)\end{array}$ & $\begin{array}{l}99.8 \% \\
(17,900) \\
0.2 \% \\
(31)\end{array}$ & $\begin{array}{l}100 \% \\
(3720) \\
0 \% \\
(0)\end{array}$ \\
\hline e & $\begin{array}{l}\text { yyл/H? } \\
\text { 'mountain' }\end{array}$ & $\begin{array}{l}\mathrm{n}_{1} \\
\varnothing\end{array}$ & $\begin{array}{l}1.5 \% \\
(6200) \\
98.5 \% \\
(395,000)\end{array}$ & $\begin{array}{l}95.2 \% \\
(331,000) \\
4.8 \% \\
(16,800)\end{array}$ & $\begin{array}{l}54.2 \% \\
(32,000) \\
45.8 \% \\
(27,000)\end{array}$ & $\begin{array}{l}48.6 \% \\
(1400) \\
51.4 \% \\
(1480)\end{array}$ \\
\hline $\mathrm{f}$ & $\begin{array}{l}\text { чоно/н? } \\
\text { 'wolf' }\end{array}$ & $\begin{array}{l}\mathrm{n}_{1} \\
\varnothing\end{array}$ & $\begin{array}{l}1.9 \% \\
(2070) \\
98.1 \% \\
(106,000)\end{array}$ & $\begin{array}{l}98.2 \% \\
(32,700) \\
1.8 \% \\
(603)^{13}\end{array}$ & $\begin{array}{l}77.2 \% \\
(4540) \\
22.8 \% \\
(1340)\end{array}$ & $\begin{array}{l}97.1 \% \\
(6840) \\
2.9 \% \\
(203)\end{array}$ \\
\hline g & $\begin{array}{l}\text { авдар/H' } \\
\text { 'chest' }\end{array}$ & $\begin{array}{l}\mathrm{n}_{1} \\
\varnothing\end{array}$ & $\begin{array}{l}67.8 \% \\
(10,600) \\
32.2 \% \\
(5030)\end{array}$ & $\begin{array}{l}35.9 \% \\
(3556) \\
* 64.1 \% \\
(6360)\end{array}$ & $\begin{array}{l}39.9 \% \\
(387) \\
60.1 \% \\
(584)\end{array}$ & $\begin{array}{l}29.2 \% \\
(35) \\
70.8 \% \\
(85)\end{array}$ \\
\hline $\mathrm{h}$ & $\begin{array}{l}\text { цэиэг } \\
\text { 'flower' }\end{array}$ & $\begin{array}{l}\mathrm{n}_{1} \\
\varnothing\end{array}$ & $\begin{array}{l}9.9 \% \\
(30,200) \\
90.1 \% \\
(276,000)\end{array}$ & $\begin{array}{l}21.6 \% \\
(12,900) \\
* 78.4 \% \\
(46,800)\end{array}$ & $\begin{array}{l}75.5 \% \\
(7220) \\
24.5 \% \\
(2340)\end{array}$ & $\begin{array}{l}26.4 \% \\
(2380) \\
73.6 \% \\
(6620)\end{array}$ \\
\hline
\end{tabular}

\footnotetext{
${ }^{12}$ It should be noted that the result for dative variant $-m$ is influenced by the homophonous possessive suffix, and such data are marked by an asterisk in (15).

${ }^{13}$ The чонод form is actually an ethnonym, rather than the dative of чоно.
} 


\begin{tabular}{|c|c|c|c|c|c|c|}
\hline & $\begin{array}{l}\text { газар } \\
\text { 'place' }\end{array}$ & $\begin{array}{l}\mathrm{n}_{1} \\
\varnothing\end{array}$ & $\begin{array}{l}0 \% \\
(248) \\
100 \% \\
(518,400)\end{array}$ & $\begin{array}{l}0 \% \\
(0) \\
* 100 \% \\
(458,000)\end{array}$ & $\begin{array}{l}0 \% \\
(0) \\
100 \% \\
(429,000)\end{array}$ & $\begin{array}{l}0 \% \\
(8) \\
100 \% \\
(380,340)\end{array}$ \\
\hline i & $\begin{array}{l}\text { гэрэл } \\
\text { 'light' }\end{array}$ & $\begin{array}{l}\mathrm{n}_{1} \\
\varnothing\end{array}$ & $\begin{array}{l}0.2 \% \\
(413) \\
99.8 \% \\
(184,000)\end{array}$ & $\begin{array}{l}0.9 \% \\
(437) \\
99.1 \% \\
(49,500)\end{array}$ & $\begin{array}{l}2.3 \% \\
(317) \\
97.7 \% \\
(13,500)\end{array}$ & $\begin{array}{l}4.8 \% \\
(383) \\
95.2 \% \\
(7520)\end{array}$ \\
\hline & $\begin{array}{l}\text { талбай } \\
\text { 'field, square' }\end{array}$ & $\begin{array}{l}\mathrm{n}_{1} \\
\varnothing\end{array}$ & $\begin{array}{l}0.2 \% \\
(940) \\
99.8 \% \\
(429,000)\end{array}$ & $\begin{array}{l}0 \% \\
(181) \\
100 \% \\
(475,000)\end{array}$ & $\begin{array}{l}0.8 \% \\
(1220) \\
99.2 \% \\
(151,000)\end{array}$ & $\begin{array}{l}100 \% \\
(9190) \\
0 \% \\
(4)\end{array}$ \\
\hline
\end{tabular}

The results show that the unstable $n$ of some nouns is optional or at least its ap-

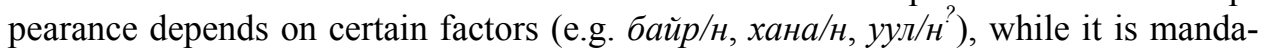
tory for others (e.g. иирээ/H). The same is valid for standard stems: some of them occur with unstable $n$ relatively frequently (e.g. иэиэг, гэрэл), while others almost never (e.g. газар, талбай - for the explanation of the latter's plural form see below). The ratio of the occurrence of certain forms can be very different for independent words and members of a phrase or compound noun containing the same word, e.g.

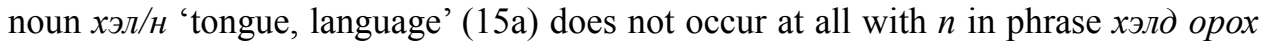
'for an infant to begin speaking'. Such difference can be observed also in the whole declension paradigm of certain nouns (16) and it may suggest a semantic distinction marked by $n$, e.g. толь/ $\mu$ is the primary 'mirror', while толь is a secondary 'dictionary'.

\begin{tabular}{|c|c|c|c|c|c|c|c|}
\hline \multirow{2}{*}{\multicolumn{2}{|c|}{ (16) }} & & & GEN & DAT & $\mathrm{ABL}$ & PLUR /-U:d/ \\
\hline & & $\begin{array}{l}\text { толь/н } \\
\text { 'mirror, dictionary' }\end{array}$ & $\begin{array}{l}\mathrm{n}_{1} \\
\varnothing\end{array}$ & $\begin{array}{l}88.6 \% \\
(70,500) \\
11.4 \% \\
(9070)\end{array}$ & $\begin{array}{l}70.9 \% \\
(56,800) \\
29.1 \% \\
(23,300)\end{array}$ & $\begin{array}{l}54.9 \% \\
(1755) \\
45.1 \% \\
(1440)\end{array}$ & $\begin{array}{l}22.7 \% \\
(804) \\
77.3 \% \\
(2740)\end{array}$ \\
\hline & b & $\begin{array}{l}\text { тайлбар толь } \\
\text { ‘(one-language) } \\
\text { dictionary' }\end{array}$ & $\mathrm{n}_{1}$ & $\begin{array}{l}25.2 \% \\
(1610) \\
74.8 \% \\
(4780)\end{array}$ & $\begin{array}{l}18.9 \% \\
(724) \\
81.1 \% \\
(3110)\end{array}$ & $\begin{array}{l}26 \% \\
(196) \\
74 \% \\
(558)\end{array}$ & $\begin{array}{l}0 \% \\
(0) \\
100 \% \\
(2170)\end{array}$ \\
\hline & c & $\begin{array}{l}\text { нэвтэрхий толь } \\
\text { 'encyclopaedia' }\end{array}$ & $\mathrm{n}_{1}$ & $\begin{array}{l}7.9 \% \\
(177) \\
92.7 \% \\
(2070)\end{array}$ & $\begin{array}{l}4.6 \% \\
(174) \\
95.4 \% \\
(3580)\end{array}$ & $\begin{array}{l}8.9 \% \\
(35) \\
91.1 \% \\
(358)\end{array}$ & $\begin{array}{l}1.6 \% \\
(4) \\
98.4 \% \\
(246)\end{array}$ \\
\hline
\end{tabular}


As it was mentioned above, the standard Khalkha plural suffix $-У У \partial$ also causes the appearance of the final nasal of unstable $n$-stems. Therefore, this suffix was also included in the analysis of stem type alternation, but at noun stems ending in a long vowel or a diphthong the $n$ before this suffix seems to be independent of the unstable nasal and it rather belongs to the suffix than to the stem, or it may be classified as a connective consonant. If two long vowels or diphthongs meet on a morpheme boundary in Khalkha, a connective consonant $/ \mathrm{g} /$ is inserted as a rule, but this $/ \mathrm{g} / \mathrm{almost}$ never appears between stem-final long vowels or diphthongs and the vowel of suffix $-У У \partial-\mathrm{a}$ consonant $/ \mathrm{n} /$ is inserted there (17). Apparently this is the standard form of the plural suffix in these cases and it has no correlation with the lack or existence of the unstable nasal before other suffixes at the same nouns, so -УУठ should be taken into consideration only at consonant stems.
a авгай 'wife'
b далай 'ocean'
авгайнууд $100 \%$ (75)
*авгайгууд $0 \%(0)$
c $ө в ө \theta$ 'grandfather'
далайнууд 99.9\% (1570)
* далайгууд $0.1 \%(1)$
d талбай 'field, square'
өвөөнүҮд 100\% (82)

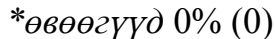
талбайнууд 100\% (9190)
*талбайгууд $0 \%$ (4)

Although the alternation of stem types usually do not affect the semantic field of nouns, there are examples where the change resulted in a full or partial semantic split. For example, $o \partial / \mu$ is mostly used in the original sense of the word as 'star (heavenly body), constellation', while $o \partial$ denotes '(movie) star, celebrity', and a third

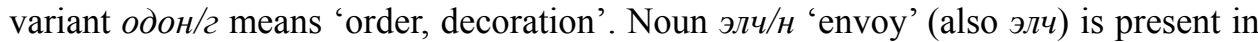
the phrases элчин сайд 'ambassador' and элчин сайдын яам 'embassy', but the latter is frequently abbreviated as an $\eta$-stem noun элчин/2 (or sometimes primary $n$-stem элчин) with the same meaning 'embassy' (and not 'envoy' or 'ambassador'). Other examples for the contrast of primary and unstable $n$-stems will be discussed in the next section.

There are certain primary (stable) $n$-stem nouns that have a much rarer stem variant without the final nasal. A non-nasal variant is regular with derivational suffixes for all primary $n$-stem nouns - as was mentioned above -, but some adjectival nouns have such a variant in other situations, too. There is no semantic difference between the basic nasal form and the non-nasal variant, and the distribution of the latter is very limited. These nouns should not be confused with noun pairs, where the stable nasal stem and the unstable or non-nasal stem are treated as separate nouns created by semantic split (e.g. хурдан 'fast' and хурд 'speed'). This non-nasal variant occurs as a modifier in "reversed" constructions where the head noun preceds the modifier with a possessive suffix $(-m A \breve{u},-m)$ attached to it (18), and also in idiomatic expressions (19).

(18) а морь сайтай (хүн) '(somebody) having a good horse (= lucky)', чадвар caümaŭ 'having good abilities' $\leftarrow$ сайн 'good'

b хавирга бүдүҮтэй (морь) '(a horse) having thick ribs' $\leftarrow$ бүдҮYн 'thick'

c айраг ц̧агаaтай (Ye) '(a season of) white kumis' $\leftarrow$ цагаан 'white' 
(19) a халуу оргих, халуy mamax 'to flame, to heat' ( $\longleftarrow$ халуyн 'hot')

b хуйm aвax 'to catch cold' ( $\leftarrow$ хуйтэн 'cold')

These examples also show that there is no clear boundary between primary (stable) $n$-stems and unstable $n$-stems, the stem-final nasal of both types disappears in certain situations, only the incidence and conditioning factors are different.

A short notice should be devoted to Mongolian (Khalkha) dictionaries. Dictionaries usually indicate if headword nouns belong to unstable $n$-stems or velar nasal $\eta$-stems, but do not mention alternations in the declension paradigm. The indication of stem type is not always consistent and not only different dictionaries may classify nouns differently, but sometimes one and the same dictionary contains contradicting data (e.g. the indicated stem type of a headword noun is not in accordance with phrases and samples containing the same noun). The following table shows some examples of such contradictions (20).

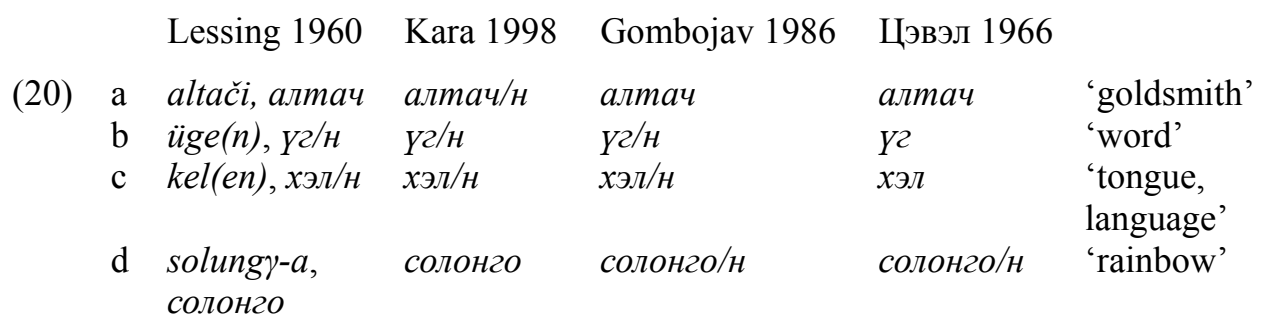

\section{Function and Role of the Final Nasal of Stable and Unstable $n$-stems}

There is no generally accepted view on the function(s) and role(s) of the final nasal of stable and unstable $n$-stems in modern Khalkha. Diachronically most of the final $/ \mathrm{n} /$ phonemes of primary and unstable $n$-stems are probably remnants of a clearly unidentified nominal suffix $-n$, while others are probably related to the same suffix, but directly inherited from a compound suffix (e.g. WM $-s U n)$. Some stable $n$ consonants go back to similar compound suffixes (e.g. WM - $\gamma$ san/gsen) or an archaic plural marker $-n$ (e.g. in the plural of WM -tAi $\rightarrow-t A n$ or $-\check{c} i \rightarrow-c ̌ i n)$.

From a synchronic point of view the unstable $n$ is frequently analysed as an empty morpheme that has no influence on the meaning or the grammatical status of the noun. This is true in several cases, but not suitable for others. Unstable $n$ fulfills a clear grammatical function if it is in opposite with stable $n$ and as such distinguishes two words with different meanings, e.g. ногоон 'green' and ногоо/н 'vegetable', гиш үун 'member' and гишүY/н 'branch', орон 'country, place' ор/н 'bed', etc. As Thompson supposes, such word-pairs could be formed from the attributive use of unstable $n$-stems by drop out of the head noun (Thompson 2008, p. 135), although it is probably not true for all cases, e.g. ногоо/н 'vegetable' seems to be a secondary formation from ногоон 'green', and the primacy of орон 'country, place' or $о p / H$ 'bed' is 
also questionable. As a secondary development unstable $n$ may form an opposite with velar nasal $/ \mathrm{y} / \leftarrow / \mathrm{n} /$, as in the case of $о \partial / \mu$ 'star' and $о \partial о н / 2$ 'order, decoration'.

Unstable $n$ can also alternate with zero in multiple words, as it was seen above. The presence of $n$ in these words can often convey the notion of concreteness or specificness, such as in чононы сүҮл 'wolf's tail' in comparision with чонын сүҮл 'wild garlic' (Janhunen 2012, p. 112). A similar example is Ye where the pure variant is used in less specific or concrete meaning as 'age, generation', and the unstable $n$-stem form means the more concrete and specific 'joint (of bones)'. The originally non-nasal stem u̧az 'time, hour, clock, watch' behaves controversially: some examples prove the function of concreteness when referring to a timing device and not a unit of time or time in general (21), while others do not (22). These examples can also be considered as examples of semantic split and formation of separate nouns.

$$
\begin{aligned}
& \text { a 'smart watch' + GEN ухаалаг иагны 99.8\% (4060) ухаалаг цагийн } 0.2 \% \text { (7) } \\
& \text { b '(wrist)watch' бугуйн цагны 98\% (7460) бугуйн цагийн } 2 \%(150)
\end{aligned}
$$

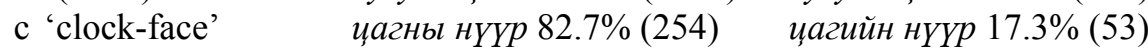

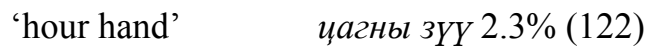

$$
\begin{aligned}
& \text { ияахий зуY 97.7\% (5100) }
\end{aligned}
$$

The extended, longer stem variant of unstable $n$-stem nouns occurs not only before certain suffixes, but also on its own (e.g. ширээ/н 'table' $\rightarrow$ ширээн, морь $/ \mu$

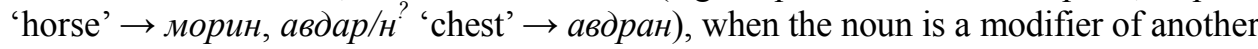
noun, including postpositional nouns and postpositions. This form of unstable $n$-stem nouns is usually categorised as a variant of nominative or as attributive. Attributive mostly contrasts with genitive and also with nominative and possessive $(-m A \breve{u},-m)$. It apparently often expresses a closer, inherent and inseparable relationship of the modifier and the head noun, as well as comparison or a more abstract relation (23).

\section{(23) а ATTR: загасан хоол 'fish food (for human consumption)'; GEN: загасны хоол 'food for fishes' \\ b ATTR: элгэн нутаг 'homeland'; GEN: элэгний өвчин 'liver disease' \\ c ATTR: морин хуур 'horse headed musical instrument', морин зөгий 'wasp (lit. horse bee)'; GEN: морины эмээл 'horse saddle' \\ d ATTR: алтан бөгж 'golden ring'; GEN: алтны уурхай 'gold mine'}

There are nominal phrases containing the same nouns where the contrast of different forms of the modifier has been neutralised (24). Although the $n$ of the attributive is clearly connected with the final $n$ of primary and unstable $n$-stems from historical point of view, its current use seems not to be limited to nouns belonging to these stem types and standard stems also occur in attributive form with $n$. For example, гэрэл 'light' is not a nasal stem (15j), but its attributive form in гэрлэн дохио 'traffic light' dominates over variants in NOM, GEN and POSS (24a). Similarly, although бичиг 'writing, script, document' is also a non-nasal stem, its attributive form бичгэн 'written' occurs 5420 times in the search results with various head nouns (e.g. орчуулга 'translation', асуулт 'question', хариулт 'answer', шийдвэр 'decision'), but it is still very 
rare in comparison with the contrasting genitive. All this can suggest that $n$ of the attributive is not necessarily a part of the noun stem, nor is related to the final nasal of unstable $n$-stems, but it can be classified as a denominal derivational suffix forming adjectives. Anyway, its distribution shows close but not exclusive correlation with unstable $n$-stems and apparently it is bound lexically to a certain extent (see also Janhunen 2012, p. 111).

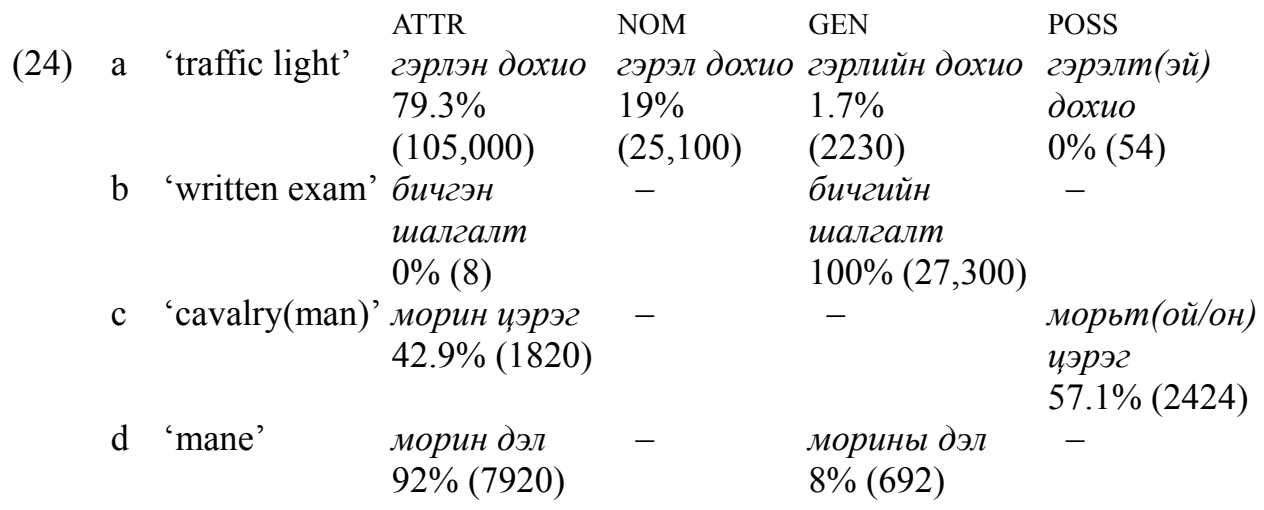

\section{Proper Names}

Proper, personal and geographical names derived from nasal stem nouns mostly behave similarly to the noun's original stem class. Alternation is observable to the same extent as it was discussed concerning the alternation of common nouns, so secondary $n$-stem and $\eta$-stem nouns retain their stem class in names, but primary and unstable $n$-stems show variance. Such name as Улаан ( $\longleftarrow$ улаан 'red') is a simple and purely primary $n$-stem noun, though others as Арвин ( $\leftarrow$ арвин 'plentiful, abundant') or historical name Тэмүүжин ( $\leftarrow$ WM Temüjin) have dual behaviour ( $n$-stem and $\eta$-stem), but in significantly different proportions (25).

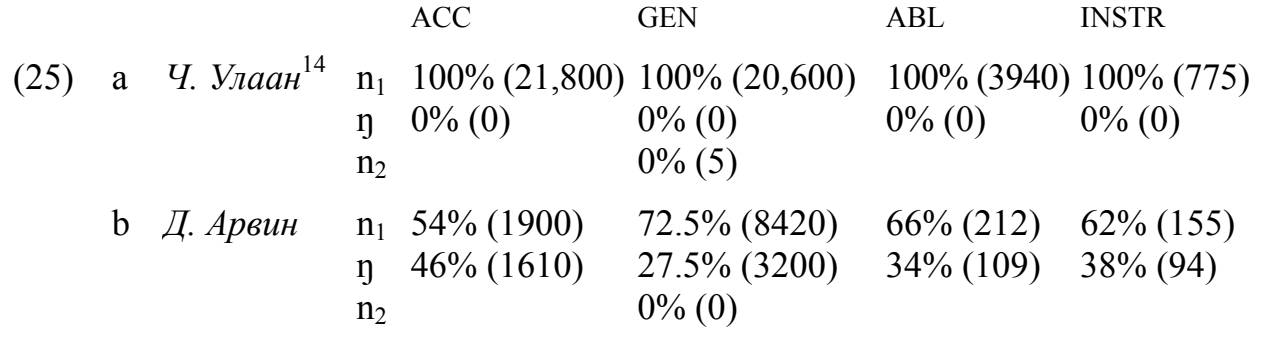

${ }^{14}$ When a name is also used as a pure common noun and it is not exclusively a personal name, I have selected from the names of members of the Mongolian Parliament and search expressions also contained the initial of the patronym of the given person in order to avoid results for common nouns. 


$$
\begin{array}{lllll}
\text { c ТэмүУжин } & \mathrm{n}_{1} 1 \%(990) & 26.4 \%(38,200) & 6 \%(342) & 0 \%(9) \\
& \mathrm{y} \quad 99 \%(72,600) & 73.1 \%(106,000) & 94 \%(5070) & 100 \%(6580) \\
& \mathrm{n}_{2} & 0.5 \%(716) & &
\end{array}
$$

Personal names created from unstable $n$-stem nouns occur with and without the unstable $n$ (e.g. нар/н 'Sun' $\rightarrow$ Наран, Алтаннаран; чулуy/н 'stone' $\rightarrow$ Чулуун, Батчулуун; туяа/н 'shine, ray' $\rightarrow$ Нарантуяа, Сарантуяа; бяруу/н 'calf' $\rightarrow$ Бяруу), but usually there is no variation in the appearance of $n$ of the same source noun. If such a name is used without the final $n$ in isolation form, it changes its stem class to standard consonant or vowel stem and the final nasal does not appear anymore in genitive, dative and ablative cases. If the unstable $n$ appears in the name's isolation form, the name behaves similarly to names derived from stable primary $n$-stem nouns.

Most of the geographical names of foreign origin (e.g. names of countries and cities) ending in /n/ behave exclusively as primary $n$-stems in Khalkha (e.g. Вашингтон, Копенгаген, Япон, Герман), a few of them do rather belong to the $\eta$-stem class (e.g. Лондон), and some names show significant diversity between the two classes (e.g. Берлин, Дублин). Country names containing element -stan (Афганистан, Казахстан, Тажикистан, Пакистан, etc.) are always treated as primary $n$-stems and no traces of a velar nasal stem variant could be observed. An insignificant variance in the suffix of the genitive case $(-u \check{u} \mu / b l \mu$ of standard consonant stems instead of $-u \check{u} / b l$ of primary $n$-stems) does not reach more than $1-3 \%$. Those names, that have a final

\begin{tabular}{|c|c|c|c|c|c|c|}
\hline \multirow{4}{*}{ (26) } & \multirow{4}{*}{ а Лондон/ट } & & $\mathrm{ACC}$ & GEN & $\mathrm{ABL}$ & INSTR \\
\hline & & $\mathrm{n}_{1}$ & $3 \%(819)$ & $35.1 \%(174,000)$ & $24 \%(6,720)$ & $16 \%(79)$ \\
\hline & & $\eta$ & $97 \%(26,100)$ & $64.8 \%(321,000)$ & $76 \%(21,200)$ & $84 \%(408)$ \\
\hline & & $\mathrm{n}_{2}$ & & $0.1 \%(253)$ & & \\
\hline & b Вашингтон & $\mathrm{n}_{1}$ & $100 \%(3560)$ & $100 \%(58,700)$ & $100 \%(35,600)$ & $100 \%(271)$ \\
\hline & & $\eta$ & $0 \%(3)$ & $0 \%(0)$ & $0 \%(0)$ & $0 \%(0)$ \\
\hline & & $\mathrm{n}_{2}$ & & $0 \%(4)$ & & \\
\hline & с Берлин & $\mathrm{n}_{1}$ & $88 \%(1785)$ & $99 \%(76,000)$ & $98 \%(2690)$ & $98 \%(221)$ \\
\hline & & $\eta$ & $12 \%(243)$ & $0.6 \%(452)$ & $2 \%(57)$ & $2 \%(4)$ \\
\hline & & $\mathrm{n}_{2}$ & & $0.4 \%(352)$ & & \\
\hline & \multirow[t]{3}{*}{ d Бостон } & $\mathrm{n}_{1}$ & $76 \%(1190)$ & $99 \%(30,200)$ & $84 \%$ (839) & $75 \%(6)$ \\
\hline & & $\eta$ & $24 \%(382)$ & $1 \%(278)$ & $16 \%(164)$ & $25 \%(2)$ \\
\hline & & $\mathrm{n}_{2}$ & & $0 \%(4)$ & & \\
\hline & \multirow[t]{4}{*}{ е Япон } & $\mathrm{n}_{1}$ & $100 \%$ & $98 \%$ & $100 \%$ & $100 \%$ \\
\hline & & & $(84,700)$ & $(48,652)$ & $(289,000)$ & $(11,400)$ \\
\hline & & $\eta$ & $0 \%(7)$ & $0 \%(0)$ & $0 \%(0)$ & $0 \%(0)$ \\
\hline & & $\mathrm{n}_{2}$ & & $2 \%(1210)$ & & \\
\hline & \multirow[t]{4}{*}{ f Герман } & $\mathrm{n}_{1}$ & $100 \%$ & $97 \%$ & $100 \%$ & $100 \%$ \\
\hline & & & $(22,400)$ & $(373,000)$ & $(39,200)$ & $(4640)$ \\
\hline & & $\eta$ & $0 \%(3)$ & $0 \%(1)$ & $0 \%(0)$ & $0 \%(0)$ \\
\hline & & $\mathrm{n}_{2}$ & & $3 \%(10,600)$ & & \\
\hline
\end{tabular}
$/ \mathrm{y} /$ in the source language usually retain it and are adopted as a $\eta$-stem noun in Khalkha (e.g. Бээжин/ح 'Beijing') (26). 


$\begin{array}{llllll}\mathrm{g} \text { Бээжин/2 } & \mathrm{n}_{1} & 0 \%(0) & 0 \%(1) & 0 \%(4) & 0 \%(0) \\ & \mathrm{y} & 100 \% & 100 \% & 100 \% & 100 \% \\ & & (28,100) & (326,000) & (22,700) & (2320) \\ & \mathrm{n}_{2} & 0 \%(272) & & \end{array}$

\section{Numerals}

Khalkha cardinal numerals are not pure nasal stem nouns, they have variants with and without a stem-final $n$, and the actual variant is chosen depending on syntactic and semantic factors. When a numeral is used in attributive position, its final $n$ appears (27). The exceptions are нэг 'one' (optional, нэгэн is possible, too), хоёр 'two' and other compound numerals ending in these two, and also such high numerals of foreign origin as сая ' $10^{6}$, тэрбум ' $10^{9}$ ' and их наяд ' $10^{12}$, (28a). Before noun хоног ' 24 hours, a day and night' the usual form of numerals is the $n$-less variant (28b). Members of compound numerals also have a form similar to their attributive except мянга '1000', which has $n$ in attributive, but no $n$ here (29).

гурван хүн 'three men', дөрвөн улирал 'four seasons', зургаан сар 'six months (period), sixth month (= June)'

a нэг/нэгэн хүн 'one man', хоёр морь 'two horses', арван нэг/нэгэн жил '11 years', дөчин хоёр настай '42-year-old', мянган тонн 'thousand tons', сая төгрөг '(one) million tugriks'

b долоо хоног 'week, seven days', гурав хоног 'three days', Сурагчид тав хоног амарна. 'Students rest five days' долоон зуун наян зургаа '786', хорин таван мянга хоёр зуун гуч ' 25,230 '

If a numeral is not in attributive position, it has an $n$-less form either in nominative or any other case $(30 \mathrm{a}-\mathrm{c})$. This is also true if the numeral is a headword of a nominal sequence (30d). Days of months and days passed after the lunar new year, however, always has $n$ and behave as stable $n$-stems, so they retain $n$ in all noun cases $(31 \mathrm{a}-\mathrm{c})$. Stem-final $n$ appears analogically even in xoёp 'two', which has no $n$ elsewhere $(31 \mathrm{~d}-\mathrm{e})$. The stable $n$ in dates is a possible remnant of an attributive form (гурван өдөр $\rightarrow$ гурван), where the head noun has been dropped out.

(30) a C. Оргильн хээр морь улсын баяр наадамд дөрөв айрагджээ. 'The bay horse of S. Orgil won three times at the national festival.'

b Таваас доош ангийнханд гадаад хэл заахыг хориглоно. 'The teaching of foreign languages for students below the fifth class will be prohibited.'

с Манай хөлбөмбөгчид гуравт оров. 'Our football players qualified into the [top] three.'

d Гэсэр хэрээ, чөтгер, оготно гурвыг алав. 'Geser killed a raven, a demon and a mouse.' 
(31) а Арван хоёрдугаар сарын долоон. 'Seventh of December (twelfth month).'

b Тэдний Үзэсгэлэн ирэх сарын гурваныг хүртэл үргэлжилэх юм байна. 'Their exhibition will continue till third of the next month.'

c Улаанбаатарын өвлийн наадам шинийн гурванд болно. 'The winter festival in Ulaanbaatar will be held on the third day of the (lunar) new year.'

d Монголчууд хоёрдугаар сарын хоёрныг Д. Сүхбаатарын төрсөн өдөр гэж хүндэтгэдэг. 'The Mongols treat with respect the second of February (second month) as the birthday of D. Sükhbaatar.'

e Зургадугаар сарын хоёрноос тасалбарын үнэ нэмэгдэнэ. 'The price of tickets will increase from the second of June (sixth month).'

Other numeral forms are derived from the $n$-less variant of cardinal numerals (32). The derived numerals are non-nasal stem nouns, except collective numerals, which have an unstable final nasal. This unstable nasal appears in attributive position and before suffixes, in the latter case the noun mostly behaves as a velar nasal $\eta$-stem (33).

(32) a distributive and approximative numbers (-AAd): арваад 'by tens, about ten', sуyzaad 'by hundreds, about hundred'

b ordinal numbers $1\left(-\partial У_{2} A A p\right)$ : зургаадугаaр 'sixth', наймдугаap 'eighth'

c ordinal numbers $2(-\partial A x)$ : аравдах 'tenth', хоёрдох 'second'

(33) а Дараа нь гурвууланг маань шүүхийн бугд хуралдаанд авчрав. 'After that he took all three of us to each court session.'

b Дөрвөн удаа нөхөрсөг тоглолт хийж, дөрвүҮлэнд нь хожлоо. 'Тhey played friendly matches four times and they won all four.'

c Би энэ жил гурван тэмиээнд орж, гурвуулангаас нь өнгө, өнгийн медаль авлаа. 'I took part in three competitions this year and got various medals from all three.'

\section{Conclusions}

The four nasal stem types discussed above are not strict categories, a wide range of nouns show variance in the use of suffixes characteristic of one or another stem type. This variance, however, shows clear tendencies, and changes in noun stems' class mostly take place in certain directions only. The increasing number of unstable $n$ stems and velar nasal stems is also obvious. Several examples of semantic split could be observed in the case of alternating stem variants.

The most complex phenomenon among Khalkha nasal stem types is unstable $n$. It is not simply a lexically encoded empty morpheme or a phonological feature in the declension paradigm of a particular noun class, but it also has certain grammatical functions such as forming modifiers, expressing concreteness or specificity and also creating semantic distinction. The $n$ of the attributive shows wider distribution than 
unstable $n$ which appears before particular suffixes; attributive is used with certain nouns of the standard stem type, too. Despite its grammatical roles, the use of unstable and attributive $n$ is still bound lexically to a significant extent since it cannot occur with all nouns.

\section{References}

Birtalan, Ágnes (2009): Bálint Gábor of Szentkatolna, A Romanized Grammar of the East-and West-Mongolian Languages. With popular Chrestomathies of both Dialects. Budapest, Library of the Hungarian Academy of Sciences-Csoma de Körös Society (Budapest Oriental Reprints: Series B 3).

Bosson, James (1964): Modern Mongolian: A Primer and Reader. Bloomington, Indiana University (Uralic and Altaic Series 38).

Finch, Roger (1987): On the Nature of Paragogic-n in Mongolian. Zentralasiatische Studien Vol. 18, pp. 52-106.

Hangin, Gombojav et al. (1986): A Modern Mongolian-English Dictionary. Bloomington, Indiana University, Research Institute for Inner Asian Studies.

Janhunen, Juha A. (2012): Mongolian. Amsterdam-Philadelphia, John Benjamin Publishing Company (London Oriental and African Language Library 19).

Jam”yan, G. (1996): Жамъян, Г.: Монгол хэлний нэр үгийн тогтворгүй “Н”-ийн учир. МУИС-ийн Ховд дахь салбар сургуулийн эрдэм шинжилгээний бичиг Vol. 7, No. 25, pp. 155-160.

Kara György (1998): Mongol-magyar szótár [Mongolian-Hungarian dictionary]. Budapest, Terebess Kiadó.

Kullmann, Rita-Tserenpil, D. (1996): Mongolian Grammar. Ulaanbaatar, Institute of Language and Literature, Academy of Sciences.

Lessing, Ferdinand D. et al. (1960): Mongolian-English Dictionary. Berkeley-Los Angeles, University of California Press.

Poppe, Nicholas (1955): Introduction to Mongolian Comparative Studies. Helsinki, SuomalaisUgrilainen Seura (MSFOu 110).

Sanžeev, G. D. (1953): Санжеев, Г. Д.: Сравнительная грамматика монгольских языков. Том 1. Москва, Академия наук СССР.

Svantesson, Jan-Olof (2003): Khalkha. In: Juha Janhunen (ed.): The Mongolic Languages. London, Routledge (Routledge Language Family Series 5), pp. 154-176.

Svantesson, Jan-Olof-Tsendina, Anna-Karlsson, Anastasia-Franzén, Vivan (2005): The Phonology of Mongolian. Oxford, Oxford University Press (The Phonology of the World's Languages).

Thompson, Mikael Adrian (2008): A Study of the Analogical Extension of the Mongolian Hidden -n Declension in Colloquial Standard Khalkha. Indiana University, PhD Thesis.

Todaeva, В. Х. (1951): Тодаева, Б. Х.: Грамматика современного монгольского языка: Фонетика и морфология. Москва, Издательство Академии Наук СССР. 